\title{
Clinical, Neuroimaging and Histological Characteristics of Non-functioning Pituitary Adenoma in Patients with Growth Hormone Deficiency
}

\author{
Mukhlisa Yu. Shakirova ${ }^{1}$; Yulduz M. Urmanova, $\mathrm{PhD}, \mathrm{ScD}^{1,2^{*}}$ \\ ${ }^{1}$ Tashkent Medical Pediatric Institute \\ ${ }^{2}$ Republican Specialized Scientific-Practical Medical Center of Endocrinology \\ named after Academician Ya. Kh. Turakulov \\ Tashkent, Uzbekistan
}

\begin{abstract}
The aim of this study was to determine the clinical and diagnostic markers of tumor aggressiveness that are predictive of tumor recurrence in patients with non-functioning pituitary adenoma (NFPA) and growth hormone deficiency.

A total of 87 patients with NFPA and growth hormone deficiency were enrolled in the study, including 31 patients after transsphenoidal hypophysectomy (postoperative follow-up from 1 to 3 years). The mean age of patients was $32.2 \pm 2.5$ years. The search for clinical and diagnostic markers of NFPA aggressiveness that are predictive of tumor recurrence after transsphenoidal hypophysectomy revealed a direct correlation with such risk factors as the young age of the patient, large tumor size, asymmetry and deformation of the pituitary gland, signs of tumor invasion into surrounding tissues, arteries, and cavernous sinus, panhypopituitarism, and the small-cell and/or dark-cell chromophobic adenomas. Preliminary data, as well as a number of studies, confirm that predictors of pituitary tumor recurrence and markers of persistent disease activity still have to be identified in order to improve the long-term management of NFPA.(International Journal of Biomedicine. 2018;8(3):197-200.)
\end{abstract}

Key Words: non-functioning pituitary adenoma $\bullet$ transsphenoidal hypophysectomy $\bullet$ pituitary gland $\bullet$ growth hormone deficiency

\section{Abbreviations}

BMI, body mass index; ESS, empty sella syndrome; GHD, Growth hormone deficiency; IGF-1, insulin-like growth factor 1; NFPA, non-functioning pituitary adenoma; PG, the pituitary gland; QL, the quality of life; TC, thigh circumference; TSHE, transsphenoidal hypophysectomy; WC, waist circumference.

\section{Introduction}

Non-functioning pituitary adenomas (NFPAs) account for $14 \%-54 \%$ of pituitary adenomas and have a prevalence of 7-41.3/100,000 population. ${ }^{(1,2)}$ Benign in origin and not provoking a hormonal hypersecretory syndrome, NFPAs are

"Corresponding author: Yulduz M. Urmanova, PhD, ScD. Republican Specialized Scientific-Practical Medical Center of Endocrinology; Tashkent, Uzbekistan.E-mail: yulduz.urmanova@mail.ru clinically challenging because they present at a late stage with local mass effects or hypopituitarism with GHD and disorders in sexual and reproductive functions. At the time of initial diagnosis, visual field defects are detected in $60 \%-80 \%$ of NFPA patients. . $^{(3,4)}$

Recurrence is one of the most troublesome clinical outcomes of NFPA. A previous meta-analysis ${ }^{(5)}$ found that NFPA recurs most often between one and five years after surgery, and that the rate of recurrence decreases after 10 years. Unfortunately, until recently there has been no consensus 
on the prognostic predictors of NFPA recurrence. No single convincing prognostic factor for recurrence was identified in a meta-analysis study on NFPA. ${ }^{(5)}$ In most studies, clinical factors of age, gender, tumor size and tumor invasion have had no predictive value for recurrence. Recently, many other factors have been introduced that influence the proliferation of pituitary adenomas, such as angiogenesis, apoptosis, Ki67 , growth factors, oncogenes, tumor suppressor genes and hormone receptors. ${ }^{(6-9)}$

The search for diagnostically significant markers of aggressiveness of NFPA in predicting the post-operation period (tumor recurrence, the need for re-operation or radiotherapy) remains an urgent problem.

The aim of this study was to determine the clinical and diagnostic markers of tumor aggressiveness that are predictive of tumor recurrence in patients with NFPA and GHD.

\section{Materials and Methods}

We analyzed the data of 87 NFPA patients (44 women and 43 men) with GHD, including 31 patients after TSHE (postoperative follow-up from 1 to 3 years). The mean age of patients was $32.2 \pm 2.5$ years.

Methods of investigation included: 1) general clinical examination, assessment of neurological status, anthropometry (height, weight, TC, WT, BMI); 2) instrumental methods of examination (visual field perimetry, colour vision, fundus oculi, visual acuity, ECG, CT/MRI of sella turcica and adrenal glands, ultrasound of reproductive organs); 3) determination of blood hormones (GH, IGF-1, LH, FSH, PRL, TTG, ACTH, testosterone, estradiol, progesterone, cortisol) in RIA using "Gamma-12" and "Strantg 300," and 4) histological examination of postoperative specimens; 5) assessment of QL by QoLAGHD questionnaire (Quality of Life Adults with growth Hormone deficiency, KIMS Study Questionnaire).

Statistical analysis was performed using statistical software package SPSS version 20.0 (SPSS Inc, Chicago, IL).

The study was approved by the Republican Specialized Scientific-Practical Medical Center of Endocrinology Ethics Committee. Written informed consent was obtained from each patient.

\section{Results}

The age-gender distribution of NFPA patients is presented in Table 1. Thirty-one NFPA patients after TSHE were divided into 3 groups depending on the histological characteristics (Table 2).

Table 1.

The age-gender distribution of NFPA patients

\begin{tabular}{|c|c|c|}
\hline Age, years & Number of men & Number of women \\
\hline $18-29$ & 10 & 12 \\
\hline $30-44$ & 12 & 9 \\
\hline $45-59$ & 13 & 16 \\
\hline $60-74$ & 7 & 3 \\
\hline$\geq 75$ & 2 & 3 \\
\hline
\end{tabular}

Table 2.

Groups of patients depending on the histological characteristics of NFPA

\begin{tabular}{|c|c|c|c|c|c|}
\hline \multicolumn{2}{|c|}{ Group 1 } & \multicolumn{2}{c|}{ Group 2 } & \multicolumn{2}{c|}{ Group 3 } \\
\hline $\mathrm{n}$ & $\%$ & $\mathrm{n}$ & $\%$ & $\mathrm{n}$ & $\%$ \\
\hline 24 & 77.5 & 6 & 19.3 & 1 & $3.2 \%$ \\
\hline Total: 31
\end{tabular}

As can be seen from Table 2, the number of patients (Group 1) with large-cell chromophobic adenoma (24/77.5\%) were the most prevalent. Small-cell NFPAs were identified in 6(19.3\%) patients (Group 2). We observed a giant recurrent malignant dark-cell adenoma with brain metastases in only one case (3.2\%) in a teenage girl (Group 3).

Clinical manifestations of NFPA in the form of endocrine and neurologic disorders were detected in $41.5 \%$ and $32.8 \%$ of patients, respectively. Symptoms of neuro-ophthalmic disorders were detected in $25.7 \%$ of patients.

In women, NFPA was accompanied by obesity, primary and secondary hypothyroidism, secondary hypogonadism, the syndrome of persistent galactorrhea/amenorrhea (symptomatic and idiopathic forms), diabetes insipidus, and ESS. In men, NFPA was accompanied by obesity, primary and secondary hypothyroidism, secondary hypogonadism, diabetes insipidus, and gynecomastia.

According to an MRI of the brain and PG, endosellar tumors were detected in 15(48.4\%) patients, endo-extrasellar tumors (mainly with suprasellar growth) - in 16(51.6\%) patients. In MRI, a soft tissue structure of NFPA was diagnosed in $16(52 \%)$ patients and a cystic structure in $11(35.5 \%)$ patients. The structure of NFPA was represented by a hemorrhagic component in $4(12.9 \%)$ cases, and both cystic and hemorrhagic components were found in $2(6.4 \%)$ of them. A pituitary microadenoma $(<1 \mathrm{~cm})$ was identified in $18(58.1 \%)$ patients, a pituitary macroadenoma $(>2 \mathrm{~cm})$ in $12(38.7 \%)$ patients and a giant pituitary adenoma in $1(3.2 \%)$ patient.

The next step of our research was to look for the most significant aggressiveness markers that play a predictive role in patients with remission and tumor recurrence after TSHE. Further, we determined the significance of the differences between such parameters as the number of patients during the remission period and the number of relapses after TSHE, with different parameters taken into account. The results of multifactorial analysis showed that there were many such markers (Fig.1).

After analyzing the data on the frequency of remissions and NFPA recurrence, a correlation relationship between different parameters and the frequency of recurrences was selectively studied.

Further, we studied risk factors (markers of NFPA aggressiveness) for the probability of NFPA recurrence in the postoperative period. Table 3 shows the predictive power of aggressiveness markers, depending on various indicators. Thus, the developed scale of aggressiveness markers of NFPA allows identifying factors according to three degrees, in view of which it is possible to plan a set of measures for preventing tumor recurrence. 


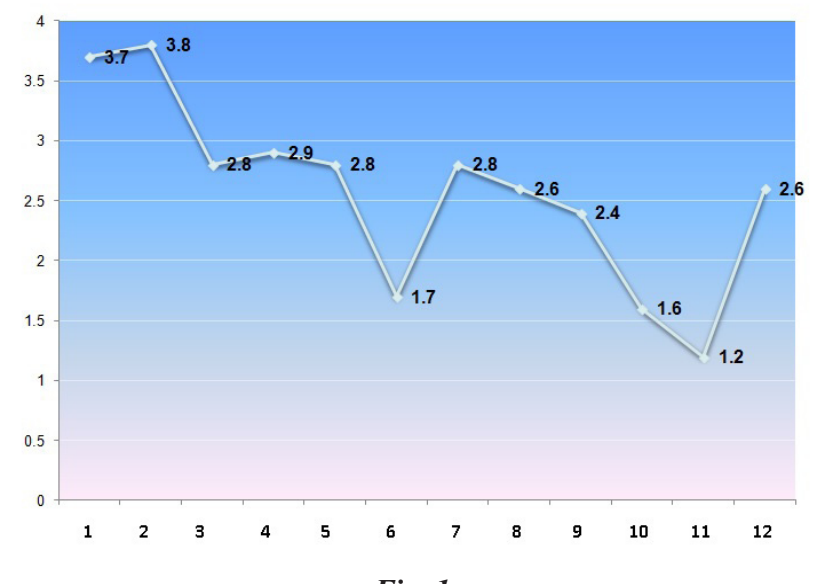

Fig. 1.

1 - small-cell NFPA; 2 - adenoma size; 3 - hypopituitarism; 4 - tumor invasion; 5 - tumor hemorrhage; 6 - rapidly progressive disease course; 7 - age; 8 - severity of disease; 9 - disease duration; 10 - asymmetry of $P G$; 11 - skull trauma; 12 - GHD

Table 3.

\section{Probability of NFPA recurrence in the postoperative period}

\begin{tabular}{|l|l|l|}
\hline Predictive power & RR & \multicolumn{1}{|c|}{ Rusk factors } \\
\hline Very high & $>3.0$ & $\begin{array}{l}\text { Young age of the patient; large tumor } \\
\text { size, asymmetry and deformation } \\
\text { of PG; signs of tumor invasion into } \\
\text { surrounding tissues, arteries, and } \\
\text { cavernous sinus; panhypopituitarism; } \\
\text { the small-cell and/or dark-cell chro- } \\
\text { mophobic adenomas. }\end{array}$ \\
\hline High & $2.0-3.0$ & $\begin{array}{l}\text { Disease duration; age; rapidly prog- } \\
\text { ressive disease course; high blood } \\
\text { cholesterol; MRI tumor hemorrhage. }\end{array}$ \\
\hline Moderate & $1.5-2.0$ & $\begin{array}{l}\text { Skull trauma; GHD; adenoma size, } \\
\text { high IGF-1 levels. }\end{array}$ \\
\hline
\end{tabular}

Approximately half of the patients with NFPA have a residual tumor after surgery. ${ }^{(10-14)}$ To date, there is no reliable marker to predict tumor regrowth after surgery. Several large series of studies evaluating postoperative tumor recurrence and regrowth have shown that the presence of residual tumors and/ or follow-up duration appear to be the two major determinants of recurrence and regrowth. ${ }^{(13-16)}$ Determining prognostic markers of NFPA aggressiveness has a large clinical value. Comparative analysis of the results obtained revealed a direct correlation with such risk factors as the young age of the patient, large tumor size, asymmetry and deformation of $\mathrm{PG}$, signs of tumor invasion into surrounding tissues, arteries, and cavernous sinus, panhypopituitarism, and the small-cell and/ or dark-cell chromophobic adenomas. It should be emphasized that stereotactic tumor biopsy is effective in predicting NFPA recurrence in the postoperative period. Our preliminary data, as well as a number of studies, confirm that predictors of pituitary tumor recurrence and markers of persistent disease activity still have to be identified in order to improve the longterm management of NFPA.

\section{Competing interests} interests.

The authors declare that they have no competing

\section{References}

1. Ntali G, Wass JA. Epidemiology, clinical presentation and diagnosis of non-functioning pituitary adenomas. Pituitary. 2018;21(2):111-118. doi: 10.1007/s11102-018-0869-3.

2. Chanson P, Raverot G, Castinetti F, Cortet-Rudelli C, Galland F, Salenave S; French Endocrinology Society nonfunctioning pituitary adenoma work-group. Management of clinically non-functioning pituitary adenoma. Ann Endocrinol (Paris). 2015;76(3):239-47. doi: 10.1016/j.ando.2015.04.002.

3. Wichers-Rother M, Hoven S, Kristof RA, Bliesener N, Stoffel-Wagner B. Non-functioning pituitary adenomas: endocrinological and clinical outcome after transsphenoidal and transcranial surgery. Exp Clin Endocrinol Diabetes. 2004;112(6):323-7.

4. Khalimova ZYu, Kholova DSh, Urmanova YuM, Alieva DA, Alimukhamedova GA, Nasirova KhK. Reproductive Function in Patients with Non-functioning Pituitary Adenoma According to the Register of the Republic of Uzbekistan. International Journal of Biomedicine.2016,6(2):133-135.

5. Roelfsema F, Biermasz NR, Pereira AM. Clinical factors involved in the recurrence of pituitary adenomas after surgical remission: a structured review and meta-analysis. Pituitary 2012;15(1):71-83. doi: 10.1007/s11102-011-0347-7.

6. Saeger W. Pituitary tumors: prognostic indicators. Endocrine 2005;28(1): 57-66.

7. Noh TW, Jeong HJ, Lee MK, Kim TS, Kim SH, Lee EJ. Predicting recurrence of nonfunctioning pituitary adenomas. J Clin Endocrinol Metab. 2009;94(11):4406-13. doi: 10.1210/ jc.2009-0471.

8. Šteňo A, Bocko J, Rychlý B, Chorváth M, Celec P, Fabian $\mathrm{M}$, et al.. Nonfunctioning pituitary adenomas: association of Ki-67 and HMGA-1 labeling indices with residual tumor growth. Acta Neurochir (Wien). 2014; 156(3):451-61; discussion 461. doi: 10.1007/s00701-014-1993-0.

9. Lee MH, Lee JH, Seol HJ, Lee JI, Kim JH, Kong DS, Nam DH. Clinical Concerns about Recurrence of Non-Functioning Pituitary Adenoma. Brain Tumor Res Treat. 2016;4(1):1-7. doi: 10.14791/btrt.2016.4.1.1.

10. Chang EF, Zada G, Kim S, Lamborn KR, QuinonesHinojosa A, Tyrrell JB, et al. Long-term recurrence and mortality after surgery and adjuvant radiotherapy for nonfunctional pituitary adenomas. J Neurosurg. 2008; 108(4):736-45. doi: 10.3171/JNS/2008/108/4/0736.

11. Losa M, Mortini P, Barzaghi R, Ribotto P, Terreni MR, Marzoli SB, et al. Early results of surgery in patients with nonfunctioning pituitary adenoma and analysis of the risk of tumor recurrence. J Neurosurg. 2008; 108(3):525-32. doi: $10.3171 / \mathrm{JNS} / 2008 / 108 / 3 / 0525$.

12. Nomikos P, Ladar C, Fahlbusch R, Buchfelder M. Impact of primary surgery on pituitary function in patients with nonfunctioning pituitary adenomas -- a study on 721 patients. Acta Neurochir (Wien). 2004;146(1):27-35.

13. Dekkers OM, Pereira AM, Roelfsema F, Voormolen 
JH, Neelis KJ, Schroijen MA, et al. Observation alone after transsphenoidal surgery for nonfunctioning pituitary macroadenoma. J Clin Endocrinol Metab. 2006;91(5):1796801.

14. O’Sullivan EP, Woods C, Glynn N, Behan LA, Crowley R, O'Kelly P, et al. The natural history of surgically treated but radiotherapynaive nonfunctioning pituitary adenomas. Clin Endocrinol (Oxf). 2009;71(5):709-14. doi: 10.1111/j.13652265.2009.03583.X.

15. Greenman Y, Ouaknine G, Veshchev I, Reider G, II,
Segev Y, Stern N. Postoperative surveillance of clinically nonfunctioning pituitary macroadenomas: markers of tumour quiescence and regrowth. Clin Endocrinol (Oxf). 2003;58(6):763-9.

16. van den Bergh AC, van den Berg G, Schoorl MA, Sluiter WJ,van der Vliet AM, Hoving EW, et al. Immediate postoperative radiotherapy in residual nonfunctioning pituitary adenoma: beneficial effect on local control without additional negative impact on pituitary function and life expectancy. Int J Radiat Oncol Biol Phys. 2007;67(3):863-9. 